УДК $811.111^{\prime} 373.45=581$

\title{
ENGLISH LOANS IN CHINESE: A FREGEAN TYPOLOGY AND FACTORS OF PRAGMATIC PREFERENCE
}

\author{
Yongming Wang \\ Ivan Franko National University of Lviv \\ 1, Universytetska St., Lviv, Ukraine, 79000 \\ lvcc66501@163.com
}

Tackled in the present study are the phonemic, meaningful, referential and graphical properties of English loanwords in the process of their copying or adapted assimilation in the Chinese recipient medium. A calculus of ten types of loanwords has been offered. The paper concludes with the models of pragmatic-cognitive preferences shared by the community of speakers that opt for a profiling of the specific modus properties of the source language elements as regards their reincarnation and adoption in the scenarios of intercultural communication.

Keywords: loanwords, adoption, Chinese lexicon, Anglicisms, intercultural communication.

Introductory remarks. The availability of English lexical loans is an intrinsic feature of a number of present-day languages. In such circumstances English plays the role of the supplier, or in the theory of language contacts the lexifier, enriching the signifying potential of the recipient, or copying, lexicon.

English loanwords started entering Chinese through Cantonese in the mid $18^{\text {th }}$ century. Ultimately they spread over other areal ecologies of the target medium thus creating ample opportunities for a substantial, versatile but still unevenly integrated layers of loanwords entering the recipient language under diverse circumstances and causing significant repercussions for its syllabary and phonotactics [8]. Notwithstanding the fact that some loanwords date back over two centuries a recent increase in lexical borrowing from English to Chinese is indicative of intrinsic Anglicization as well as a societal trend of modernization, which seems a consequence of the implementation of the "open door" policy begun in the late 1970s.

The main aim of the present paper is to present an interplay of contact scenarios and entry paths during versatile processes of the penetration of Anglicisms into the Chinese lexicon. Presumably, this will enable us to arrive at a calculus of types of Chinese Anglicisms based on modussensitive and adoption-induced feature(s) of these units as well as to propose a dynamic model of speaker-chosen priorities in the choice of phonetic, semantic or graphical means of copying.

Previous works. Even though an interest in the English loans in Chinese is rather long-lasting with a number of works published in the course of the last sixty years, including dictionaries of neologisms, with loanwords as a category in the latter as well as separate, though smaller, dictionaries of loanwords, no exhaustive classification of their types follows from what has been published so far. An attempt to draw on the factual evidence scattered in as wide a list of publications as could be collected with present-day bibliography searches revealed that most works have

(C) Y. Wang, 2017 
appeared within hardly more than the last fifteen years. It is not that there was no interest at all in the said borrowing processes before. The publications span from the 1828 (reprinted in 2001) first list of Cantonese borrowings from English compiled in Hong Kong by Morrisson (see more on this in [8]) through the seminal 1958 works on loanwords and hybrid words in modern Chinese by Gao Mingkai and Liu Zhengtan to an interest on the part of sinologists world wide [1-2; 3-7; $12 ; 16 ; 18-24]$. The common issues in the study of Chinese Anglicisms are the historical periods of their penetration, the intermediate links on the part of the Japanese counterparts as well as thematic-conceptual affiliations of the referents. Recently a novel thematic area has opened up to the processes of Chinese borrowing from English in the sub-languages of information technology, internet and online communication that are particularly characteristic of the interaction medium of young speakers. Here interesting nounce borrowings would be coined as an experience of translanguaging, e. g “offer 雨(yǔ)' and 'AD王(wáng)' [10, p. 27 ].

The assessment of the inventory of such loanwords is quite a complex matter as part of these units tended to be ousted in the processes of rivalry between synonymous creations or change of preference strategy in the very process of copying. Loanwords would be also 'hidden' amidst a much wider and open-ended category of neologisms and ad hoc creations within numerous specialized spheres of terminological reference.

Theoretical background. The logographic nature of written Chinese poses an impediment to those loans that function as phonetic annotations. In the receptive lexicon of the said contacts the overall principle should still hold that graphemes (Chinese hieroglyphs) encode a phonetic value together with the meaning.

There are many cases where one English word corresponds to several loan forms in Chinese. This may be a result of different ways of borrowing, i.e., as a phonetic loan, a semantic loan or a graphic loan or a combination of two or even three. The differences in the adoption of these strategies may also be related to territorial sub-norms or dialectal argots of Chinese. In such cases of variant strategies the phonetic paths generally tend to give way to more meaningful (semantic) alleys. The intrinsic property of the Chinese morphemes to carry meaning and the ability of the adopted loanwords to fulfil the "exotic" expressive function account for the fact that a large number of phonetic loans die out gradually, meanwhile their semantic counterparts survive, which fact may cast some light on the cognitive and pragmatic-sensitive, meaning wise relevant peculiarities of lexical contacts between typologically distant languages.

The language consciousness of the Chinese tends to discern the meaning of a word or compound by splitting it into separate characters. This mode of mental-semantic processing rests on the mono-syllabic lexicon as a fundamental typological feature of Chinese. It brings about the overwhelming tendency of stacking (concatenating) of meaningful characters, which when taken separately can be single-character words in modern Chinese This in turn reinforces the analytical, or even fusion-focused language-thinking (cognition) in the copying process. Nevertheless, part of the characters envolved in this process when taken separately are semantically void.

The monosyllabic characters are the stems of words in Chinese. The morphemes in a word and constituents in a compound in English are copied equally by Chinese syllabary. These peculiarities provide a natural "playground" for the borrowing process in Anglo-Chinese lexical relationships. Most modern Chinese multi-morphemic words are disyllabic. One possibility is that one of the characters is responsible for the conveyance of the concept and the other for what would convey the word-forming marker from the donor language. The two-syllable Chinese words would most typically correspond to the principle of construal in an English compound. 
Chinese characters, basically, they are monosyllabic and meaningful by a "one-to-one" principle. We believe that this typological feature of the recipient language encourages the adoption of English loans into Chinese through word-for-word or looser translation as well as through a subtle interplay of multiple adoption strategies in a loanword. Thus semantic adaptation and graphic adoption can underwrite or play down phonetic loanwords.

Modern Chinese is a morpheme-centred language where compounds and even derivatives are morphologically motivated in a 'constituent-pictogram' way. Mono-morpheme words are 'pictogram simplexes' though sometimes with an 'inbuilt' element.

These peculiarities provide a natural 'playground' for the borrowing process in AngloChinese lexical relationships. Most modern Chinese multi-morphemic words are disyllabic. One possibility is that one of the characters is responsible for the conveyance of the concept and the other for what would convey the word-forming marker from the donor language. The twosyllable Chinese words most typically though would correspond to the principle of construal in an English compound.

The rise of morphological motivation and hence the disyllabic structure of a Chinese lexeme is more visible in Modern Chinese in comparison with classical Chinese. Modern Chinese speakers are subconsciously more accustomed to the practice of figuring out the meaning of a word by looking into its constituent characters or morphemes embarking on the area of word analyzability, i.e. examining it by way of decomposing the semantic wholeness into the respective constituents. Thus when the language does adopt a new concept from another language it would prefer to resort to literal translation or semantic loan so that the morphemes of the items borrowed may carry constituent meaningful entities. For instance, the English word 'stick' was initially transliterated as司的克 (sīdekè) which was widely accepted in China before 1949 for a walking stick, but the term had become obsolete and was substituted by a modified translation that made use of the native constituents - 手杖(shǒuzhàng) (lit. hand stick). A similar replacement is noticeable in a shift from sānwénzhì 三文治 ('sandwich') to a more up-to-date 三明治 (sānmíngzhì) [10].

In the first few decades of the $20^{\text {th }}$ century, when entities of the western civilization got introduced to China through English, there was a time when Chinese translators took a short cut by merely transliterating the new terms. For instance, “democracy' appeared as德莫克拉西 (démòkèlāxī) and 'science' as 赛因斯 (sàiyīnsī). A slightly modified phonetic image was adopted in Chinese for the English loans telephone which sounded 德律风 (délüfēng), inspiration that ran 烟士批里纯 (yānshìpīlǐchún). Also, president which was rendered as伯里胥天德 (bólǐxǐtiāndé) and ultimatum that was accepted in a modified phonetic form of 哀的美敦书 (āidìměidūnshū). These long and unintelligible words proved unpopular with Chinese speakers. Soon 'democracy' 德莫克拉西 (démòkèlāxī) was ousted by 德先生 (déxiānsheng) (lit. 'Mr De') and 'science’ 赛 因斯(sàiyīnsī) by 赛先生(sàixiānsheng) (lit. 'Mr Sai') leaving only the first character to indicate the sound and using the two-syllable structure 先生 (xiānsheng) to imply 'something important'.

Nowadays, the above transliterations have been replaced by more motivated translations, viz. 民主(mínzhǔ) (lit. 'people domination') for democracy and 科学 (kēxué) (lit. 'science study') for science, respectively. Likewise, the penetration into Chinese of the concepts of 'president' through the translation loan 伯里胥天德 (bólǐxǐtiāndé, lit. uncle; inside; roeal seal; sky; morality, and that of 'ultimatum' through the translation loan 衰的美敦书 (āidiměidūnshū), lit. sad; and so on; beauty; the surname 'guo', was also accompanied by simplification, which contributed to the 'updated' semantic loanwords, namely总统 (zǒng tong) (lit. 'general administrator') and 最后通牒 (zuì hòu tōng dié) (lit. 'last diplomatic notice'). The adduced examples of semantic 
loans, notwithstanding the fact that the first three of them are direct hieroglyphic (graphical) borrowings from Japanese, have become so well-established in the recipient language that they are no longer treated as borrowings but rather as native words. Divulging or, in view of the cultural and typological distance between English and Chinese, in some sense even 'unravelling' the semantic idiosyncrasies of such hidden Anglicisms is of interest for rediscovering the semantics of inter-ethnic transitions and intercultural communication in this pair of interacting languages.

A similar scenario can be discerned in the swap of the Chinese Anglicism ice cream and even the name of a scholarly discipline biology from 埃士忌廉 (āishìjilián) and 拜欧劳介 into 冰激 凌 (bīngjīlíng, lit. ice; excite; dawn, and 生物学 (shēngwùxué) lit. live; thing; study. Further exemplification of this situation is available in the transition from the phonetic loans atom 阿 屯 (ātún), parliament巴力门 (bālìmén), comprador 刚白度 (gāngbáidù), ideology 意德奥罗基 (yìdéàoluójīi) and homepage 烘培鸡 (hōngpéijī) into the semantic loans atom 原子 (yuánž̀), lit. original elementparliament 国会 (guóhuì, lit. country conference, comprador 买办 (măibàn), lit. purchase manager; ideology 意识形态 (yìshíxíngtài) lit. 意识yìshí concious; xíngtài pattern, and homepage 主页 zhǔyè, lit. main; page....

The foreign origin of such loan translations is oftentimes unrecognizable to Chinese speakers. It could be that the two versions of a borrowed concept from English into the Chinese language for a time were in parallel use with a plausible preference for one or the other by the specific functional environment. Thus, the Anglicisms 维他命 wéitāming which is a phonetic loan from the English vitamin was ultimately ousted by the semantic loan 维生素 wéishēngsù, lit. maintain; alive; element, after both of them had been in parallel use for some time. A similar parallel use is presumed to have been in place with respect to the borrowed scientific term penicillin in its phonetic variant forms pánníxīlin, pánnixxilín, and the respective loan translation 盘尼西林,, qīngméisù, lit plate; nun; west; woods as well as a transliterated variant of the lexeme telephone as délüfêng, or in the hieroglyphic notation 德律风, which was later on, possibly owing to a wide dissemination, domesticated through the loan translation of lit. 'electric speaking', or diànhuà, expressed by two Chinese characters 电话. Cf. smartphone, 智能手机 zhinéng shǒujī, lit. intellect-telephone, also, telephone card, 电话卡dianhuaka (dianhua, telephone; ka, card) or 显示卡xiănshìkă display card or smart card. Curiously, another widely spread referent "internet” has a fully semantic realization, 互联网 hùliánwăng (mutual-to connect-net), and two hybrid forms, “yīntèwăng” 因特网 (reason-specialnet”) and “ying-te-wang” 英 特网 (England-special-net) [16, p. 37; cf., also, 15].

The duration of parallel use of some phonetic loans and their loan translation counterparts in the recipient language would call for a further study in a wider subject area of codification reconstruction.

This demarcation line between the Anglicisms that are in actual use now and those that got out of use is traceable in many referential spheres of language contacts. For instance, in politics - anarchism 安那其主义 (ānnàqízhǔyì, utopia 乌托邦(wūtuōbāng), ultimatum 哀的美敦书 (Bidìměidūnshū ) as opposed to the ousted ones parliament巴力门(bālìmén), president 伯理胥 天德 (bólǐxǐtiāndé), tyrant 代兰德 (dàilándé, democracy 德谟克拉西 démókèlāxīdé), fair play 费厄泼 (fèièpō). In arts. Romance 浪漫史 (làngmànshǐ), rumba 伦巴 (lúnbā), guitar 吉他 (jítā), violin 小提琴 (xiăotíqín) as opposed to essay 爱说 (aishuō), violin 梵阿玲 (fànālíng).

The situation seems quite dubious. On the one hand, roughly two thirds of phonetic loans are believed to be replaced by semantic loans. This fact contributes to the lessening of transparency of the results of borrowings. Indeed, semantic loans could bear no reference to the original source unless such reference is especially 'brought to light' through pragmatic motivation. On the other 
hand, a phonetic loan is characterized by an expressive function within the respective sphere of inter-language contacts. Hence, by and large the recipient language opts for a semantic translation as an outcome of its contacts with English, although a number of examples are characterized by the adoption of the mere sounding pattern from the source language. Typically it is somewhat modified owing to the peculiarities of the recipient phonology.

In the case of proper names, transliteration borrowing seems acceptable and popular, but when a proper name is meaningful, the recipient lexicon is likely to resort to a semantic loan. For example, 'Oxford' appears as 牛津 (niújīn) (lit. 牛 niú for 'ox', and 津jīn for 'ferry' or 'ford') rather than 奥克斯福德 (àokèsīfúdé) which would be a phonetic loan. Likewise, the Black Sea is opted for 黑海 (hēihăi), lit. black; sea, and not 布莱克海 bùláikèhăi (lit. textile; wasteland; restrain; sea) and Watergate is preferred as 水门(shulmén) (lit. water ; gate ) rather than 怀特门 (huáitèmén), (lit. mind; special; gate). It is only the context that helps to avoid the empty semantic reading of such phonetic loans.

In graphic loanwords from Japanese the characters are not only similar to the Chinese ones, but also meaningful. One speaking example is the importation of karoshi 过劳死 (guòláosǐ), lit. over-tiredness-death, from Japanese. The intense competition, high speed of life and heavy burden of work in modern society may be a factor of 'sudden death because of fatigue from overwork'. Neither Chinese nor English has a proper word to describe this effect, so Chinese borrowed 过劳死 (guòláosî) graphically with the corresponding pronunciation, and English borrows a slightly modified phonetic loan 'karoshi'. The latter has even entered the Oxford English Dictionary in 2002.

Although quite a number of phonetic loans were ultimately substituted by semantic loans in the course of the interaction between the two lexicons, some phonetic loans tend to oust loan translations and both phonetic and graphic loans alone have proved quite popular during the recent decades becoming such 'part-and-parcel' sounding traits of modern every day Chinese rapport as cool 酷 (kù), dink 丁克 (dīngkè) and MTV (MTV- 音乐电视 (yīnyuèdiànshì), lit. music electronic version. Now such in-lets are treated as naturalized, so when hearing have a party in 开派对 (kāipàiduì), dine at the MacDonald's 吃麦当劳 (chīmàidāngláo), (lit. eat; wheat; equal; working) or 吃金拱门(chījīngǒngmén, lit. eat; golden; arched; door ) and dance disco 跳迪斯 科 (tiàodísīkē ) or 蹦迪 (bèngdí) there is little, if any, feeling of foreign words.

It is noteworthy that in a tripartite penetration of the Anglicism cartoon into the Chinese target medium as a graphic borrowing via Japanese 漫画 (mànhuà), or the recipient medium semantic loan 动画 (dònghuà), (lit. moving picture), it is the phonetic loan 卡通 (kătфnng) which gains precedence owing to clarity, simplicity and fixed grammatical function - all the three factors of the 'molding' convention. Some sources of the process of English-Chinese borrowing end up as rivalling forms in different variants of Chinese: cf. Eng. Jumbo and mainland China 大型 飞机 (dàxíngfēijī) but Hong Kong 珍宝机 (zhēnbăojī) and Tai Wan 大型客机 (dàxíngkèjīi) also Eng. film and mainland China 胶卷 (jiāojuăn, but Hong Kong 林菲 ( línfēi ) and Tai Wan 底片 (dǐpian). Likewise, Eng. bus and mainland China 公共汽车 (gōnggnnngqğchē), but Hong Kong 巴士 (bāshì ) and Tai Wan公车 (gōngchē). Respectively, Eng. taxi and mainland China 出租车 (chūzūchē), but Hong Kong 的士 (díshì ) and Tai Wan 计程车 (jìchéngchē); Eng. toffee and mainland China 太妃糖 (tàifêitáng) Hong Kong 太妃糖 (tàifēitáng) and Tai Wan 塔妃糖 (tăfēitáng. Finely, Eng. DINK ('dual income no kids’) and mainland China 丁克 (dīngkè ) or 丁克家庭 (dīngkèjiātíng), but Hong Kong 顶客士 (dǐngkèshì and Tai Wan 丁克一族 (dīngkèyīzú).

Hence the adoption path of an English lexifier into the Chinese receptive medium can lead us into the sound, image and sense of this element in a new alien setting. A comprehensive study of 
the pragmatic priorities in the paths of entry for Anglicisms into the Chinese lexicon is conceivable on the basis of the Fregean paradigm where the vertices are imputed the phonetic, graphical and signifying values, respectively, and the borrowing scenarios may involve any of the two or even all three of these characteristics.

Results and discussion. We will start the discussion of the types calculus of Chinese Anglicisms with phonetic loans as they come at the forefront of any inter-language interaction leading to borrowings.

Phonetic loans (P). An alien concept may enter the recipient medium through the endeavour to reflect what it sounds like back in the source language by producing the intended matching effect when the lexeme in question is enunciated in the target language.

This transliteration technique is not free of pragmatic undertones, or even drawbacks. One is that since the Chinese characters were not designed to represent sound, the result is usually just a rough approximation of the original sound. This is caused by the deficiency of the immediate constituents sensitivity threshold necessary for the 'finely tuned' replica of the original. The earliest such group of borrowings chronologically is found with respect to religious terminology: cf., Eng. Amen and Chin. a-men or a-mon, Engl. Satan and Chin, sa-dan or sa-tan, Engl. Judas and Chin. you-da or iau-ta. As regards a hieroglyphic notation these pairs are imputed a single writing.

Moreover, since the characters may be pronounced very differently under various dialects, what is a close approximation under one dialect may not be under another. Although this fact should not necessarily be related to the dialectal status of borrowings and variant phonetic loans of the same referent may fall on the amplitude of precision in transliteration that proves supra-dialectal. In short, it is not impossible for the same foreign word to have multiple Chinese transliterations.

There is one other disadvantage. Since every Chinese character is meant to represent a meaning in the lexical system the transliterated word is just nonsensical. But sometimes the character that is meant to be a mere sound imitation of the original donor input is homonymous with a character rendering a meaning that has nothing to do with the meaning of the borrowing in question. Such a borrowing is to be uttered as a mere sound sequence disregarding a plausible meaning of the character. Sometimes indeed a string of characters in the target language that stands for a phonetic borrowing falls on a specific, even playful, sense reading as if it were designed by the invisible hand of the agent of contact on purpose. Yet basically phonetic loans are detrimental to the intrinsic characteristic of the Chinese writing system where we see the character(s) and know their meaning(s). Hence phonetic loans could be quite confusing to Chinese speakers. As described in the famous novel The Teahouse (茶馆 cháguăn) by Lao She, the transliteration of 'trust' as 托 拉斯 (tuōlāsī) was misinterpreted into 'drag in and pull in, tear into two if not obedient', correspondingly 拖进来 tuōjìnlái 拉进来 lājìnlái 不听话就撕成两半 (bù tīnghuàjiùsīchéngliăngbàn).

The phonetic loans seldom occur on their own. Oftentimes, alongside a phonetic loan a meaningful association arises. Hence transcription can lso be made more complex through a semantic element.

The words of the former category have a Chinese form in which the written characters coincide with similar sounds. The Chinese characters involved are mostly phonetic signs, usually only signifying sounds, regardless of their original meanings, e.g. Eng. bus, bye-bye, brandy, carnival, clone, disco, Disney, gene, punk, shampoo, model, sofa, cola, yoga (the last word originally from Sanscrit) are conveyed through the Chinese 巴士 bashi, 拜拜 baibai, 白兰地 bai lan di, 嘉年华 jia nian hua, 克隆 ke long, 迪斯科 di si ke, 迪斯尼 di si ni, 基因 ji yin, 朋克 peng ke, 香波 xiang 
$b o$, 模特 mo te, 沙发 sha fa, 可乐 ke le and 瑜伽 yu jia, respectively, yielding a fairly close, but still imprecise representation of the original's phonology.

The phonetic loans are adopted in the way that a Mandarin form represents a pronunciation that is similar to that of the source language counterpart. However, it can also develop certain meaning associations to the source form. For instance, the type of vehicle signified by the English noun bus in China is 'gong gong qi che' written with four Chinese characters. Understandably, this is a semantic translation. The 'notion of the bus' was also borrowed phonetically as 'bashi'. At the beginning it was characteristic of Cantonese in Hong Kong. Now both forms - 'bashi' and 'gong gong qiche' are in daily use throughout China. Interestingly, 'bashi' is also shortened to 'ba'. It resembles an element of a compound in the 'English sense', which is a Chinese twomember fusion, but in some sense it even looks as a suffixoid. It figures in such formations as 'daba', that stands for 'a large bus' as well as, 'zhong ba', standing for 'a middle-size bus' and even 'xiaoba', for 'a mini bus'.

A phonetic loan, also referred to as transliteration, has a phonological similarity with the donor language form. This 'transliterated' loanword is used in the borrowing language with the sounding that is the closest possible to the original word. In adopting phonetic loans, sometimes totally new characters were invented for the loan syllables, as in 咖啡 (kāfēi ) standing for the loan coffee and 柠檬 ( níngméng), respectively, for lemon. Sometimes the characters chosen to represent the sounds of the syllables in the donor word lose their original meaning. For example, the characters in 巧克力 ( qiăokèlì ) being just accidental to the corresponding meanings of characters, namely 'opportunity - to be able to - power, are meant to coincide with the sounding of the English noun 'chocolate'. The three separate morphemes when combined are just homonymous with the their meaningful significations when each is used separately viz. 巧 qiăo, lit. skilful, 克 kè, lit. restrain, and 力 lì, lit. power, strength. The ultimate juxtaposition is sense wise void.

Phonetic loans are usually a direct outcome of language contact, but very many, or perhaps even most of them give way to semantic loans in the course of their attempted adoption because Chinese characters are basically meaningful and they have a special preference for meaning. Those phonetic loans that are destined to survive could be marked expressively by (an) additional phonetic character(s).

When one or more Chinese characters are used as a meaningless syllable to represent the sound of a donor word, this kind of borrowing is referred to as a pure phonetic loan or a complete transliteration, such as sofa 沙发 shāfā (lit., sand-send), cheese 芝士 zhīshì, (lit., seed-person). It could also be that such characters are associated with no sense at all when they stand on their own, curry 咖哩 kālǐ, (the constituents devoid of meaning when treated separately, morphine 吗 啡 măfêi (the constituents semantically empty).

Here the Chinese characters lose their original meaning and become mere phonic signs only to signify the foreign sound or 'created' for the sounds as in the last two cases. Usually such loanwords constitute an indivisible unit comprising only one morpheme. As is the case of aspirin 阿司匹林 (āsīp̌lín), where the English original has three syllables while the borrowed form consists of four characters but only one morpheme, which cannot be further divided into smaller meaningful units.

Phonetic-semantic loans (P-S). The Chinese character is not only the minimum combination of sound and meaning, but the minimum combination of sound, meaning and form. When adopting loanwords, simple translations of the meaning would be more acceptable but the foreign flavor is then to be lost. It will be best if a loanword borrows more than one element of sound, meaning 
and form, e.g. coca-cola 可口可乐 (kěkǒukělè, (lit. 可口 kěkǒu- good, 可乐 kělè taste-happy). Novotna calls such constructions 'hybrid words' [17]. Similarly, the automobile brand BWM is rendered hyerogliphically 宝马, baoma, corresponds literally, and non-arbitrarily, to 'precioushorse'. Sometimes they are referred to them as 'semantic-phonetic hybrid'. Zuckermann uses the term 'phono-semantic matching' [24].

A phonetic-semantic loan refers to the situation when the Chinese characters affect both the sound and meaning of the donor word. Then the borrowed item becomes a perfect match of the original one, e.g. Benz (奔驰 bēnchí lit., run quickly - speed ), bandage (绷带 bēngdài lit., stretch tight - belt ), pump (洜bèng - lit., water machine), cooloe (苦力 kǔlì lit., hard - power), hacker (黑客 hēikè lit., black - visitor), sumburn (晒斑 shàibān lit., shine - spot), vitamin (维他 命 wéitāmìng lit., maintain-it-life), utopia (乌托邦 wūtuōbāng lit., crow-hold-country), hippies (嬉皮士 xīpíshì lit., play-skin-person), opium (鸦片 yāpiàn lit., crow-piece), pudding (布 丁, bùdīng, lit. cloth - man/fourth).

Loanwords of this kind are sometimes called perfect loans or coincidental phonetic-semantic loans. This type is considered to be the best strategy for introducing foreign words into Chinese.

Phonetic-semantic loans are hybrids. Hybrids are words adapted from foreign languages using a combination of different strategies. Such Anglicisms are actually a combination of phonetic loans and loan translation. The common strategy here would be to use the characters which denote no meaning to imitate phonological forms of English words and then add some other characters at the end of these loanwords to signify their varieties. In this type of loans, the phonemic and semantic components are two separate parts, which distinguish them from phonemic semantic loans, for example, phonemic loans with semantic associations in which a single phonemically adapted form dually conveys phonological similarity and meaning links.

Hybrid loans in Mandarin are those in which a native morpheme is added after the phonemic transliteration of the source form. The inserted morpheme servers to indicate the semantic category of the word and hence facilitates understanding. For instance, Eng. AIDS (name of a disease) and bowling (name of a ball game) are borrowed into Chinese as ai-zi-bing, lit. love-generate-disease, and bao-ling-qiu, lit. protect-ball-game. The morphemes bing (disease) and qiu (game), added to the phonemic correspondent of the source form, indicate the semantic category of the loan.

The hybrids that combine a phonetic principle with the semantic one can alternatively be formed in such a way that the source form is partly phonemically transcribed and partly morphemically translated. For instance, Eng. Barbie Doll (the brand name of a doll) entered Mandarin as $\boldsymbol{a}$-bi $\boldsymbol{w} \boldsymbol{a}-\boldsymbol{w a}$ (palm tree-to compare-doll). The first half "Barbie" is adapted through phonemic transcription, giving rise to "bar-bie" and the second half, "doll" is a translation, giving rise to "wa-wa". Sometimes both a morpheme-by-morpheme translation and an addition of a semantic indicator are employed.

In many cases, an exotic word from the donor language could be borrowed in more than one way, consequently giving rise to multiple borrowings. For instance, Eng. UFO may correspond in Chinese both to 幽浮, you fu, and 不明飞行物 bùmingféixingwù, translated as 'the unknown flying object' or the domesticated Chinese 飞碟 fēidié, lit. a flying saucer. Multiplicity of borrowing outcomes is characteristic of the interlingual nominations in science, e.g., Eng. trinitrotoluene penetrated into Chinese phonetically as 梯恩梯, ti en ti, or as 三硝基甲苯 $\mathrm{C} 6 \mathrm{H} 2 \mathrm{CH} 3(\mathrm{NO} 2) 3$, ( sānxiāojījiăběn ) combining both a hieroglyphic and chemical notations, or, eventually, through the domesticated variant 黄色炸药, ( huángsèzhàyào, it. yellow dynamite. Likewise, Eng. SARS may be rendered in Chinese as a phonetic loan 萨斯, sa si, or just descriptively as 严重急性呼 
吸综合症 ( yánzhòngjíxìnghūxīzōnghézhèng ) 'severe acute respiratory syndrome', eventually also as 非典fēidiăn /非典型性肺炎 fēidiănxíngxìngfèiyán 'atypical pneumonia'. Multiplicity of the contact is additionally strengthened by the attested English abbreviations, or eventually literal replica as in Eng. e-mail, Chin.

伊妹儿,yi mei, respectively, 电子邮件 diànzǐyóujiàn / 电邮diànyóu 'electronic, curiously, in Chinese same as electric, mail' or replicated e-mail/email as an alien infiltration into the fabric of the Chinese recipient lexicon. No Chinese counterpart is conceivable in the case of established internationalisms, cf. Eng. CEO was adopted by Chinese as 'chief executive officer' or even CEO. Belonging to the category of English-prompted internationalisms are also names of some commodities e.g. hotdog règǒu 热狗.

Phonetic loans with a label. A concomitant feature of transliteration while adopting English loanwords into the Chinese lexicon is a pre- or postpositive categorizer, respectively $\mathrm{P}+\mathrm{L}$ and $\mathrm{L}+\mathrm{P}$. Such instances are sometimes assigned the status of hybrids as well. In Masini [14] the term, 'hybrid' is used to indicate loanwords composed of a phonetic loan of the donor word plus an autochthonous element usually used to indicate the semantic category of the word. Loanwords of this kind are 'phonetic calques'. Haugen uses the term 'hybrid' broadly: "hybrid is sometimes used in the sense of loan blend" [13, p. 214]. To avoid confusion, we will call loanwords of this group, which are characteristic of Chinese, phonetic loans with a label. When the transliteration part is not meaningful enough or is too short (usually consisting of only one character), a label is often added to mark the category of the word and to keep the balance in pronunciation as well. The label may appear before the transliteration, e.g., bar 酒吧 jiǔbā (lit., alcohol-crackling) and tart 蛋挞 dàntà (lit. Egg-whip), but in most cases it follows the transliteration, e.g., beer 啤酒 píjiǔ, truck 卡车 kăchē , card 卡片 kăpiàn (lit., block-piece), motocycle 摩托车 mótuōchē (lit., rub-hold-vehicle), disco 迪斯科舞 dísīkēwǔ (lit., flavor-this-science-dance). Chinese has a high preference for two character words, the label character in a single syllable loan performs both functions of showing the meaning and making up the sound prosody wise and will most likely remain where it is. While the label character in the multi-syllable loan often falls out when the meaning of the loanword is well established. So bowling (保龄球 băolíngqiú lit., keep-age-ball) turns into 保龄 băolíng (lit., keep age) and champagne which is rendered by three characters - 香 槟酒 xiāngbīnjiǔ, lit. 香xiāng sweet smelling, 槟 bīn which is devoid of any meaning when used singly, and 酒 jiǔ, lit. alcohol gets clipped into 香槟 xiāngbīn. In this case, the hybrid word becomes a pure phonetic loan. The categorizer may also be involved in the kind-gender relationship arising during the loan adoption, e.g. 吉普车 jipuche, where apart from 'jeep' rendered by the first two characters the borrowing also contains a hyperonym 车 che, lit. car, automobile. Likewise, the solution for the English in-let sardine falls on 沙丁鱼 shadingyu where the first two characters are a phonological loan for 'sardine' and third one - 鱼 yu for the gender term 'fish'. Also, cf. the use of gender terms clock, ice and wine in the borrowings Big Ben, 大笨钟 dàbènzhōng 大 (big)；笨 dull ) 钟 (clock) ; (ice) ice-cream 冰激凌 bīngjīlíng, Champagne 香槟酒 xiāngbīnjiǔ. Although sometimes the use of the generic term seems more motivated as without it the adopted borrowing would remain ambiguous for the target audience, as Dowling (paper) would make sense only with the explicit third constituent: 道林纸 dàolínzhǐ [11].

There is a second group of phonetic loans with a label, which usually are not regarded as loanwords, at least according to the treatment in in the fifth edition of "The Contemporary Chinese Dictionary" (CCD5). It occurs when a phonetic loan is well established, it is likely to become a morpheme to participate in forming new words, as in the cases of 大巴 dàbā (big bus), 中巴 
zhōngbā (bus of medium size), 小巴 xiăobā (mini-bus), and 沙发床 shāfāchuáng (soft bed), 沙发 罩 shāfāzhào (sofa cover) in which 巴 bā comes from the phonetic loan of 巴士 bāshì (bus) and 沙发 shāfā from "sofa". The same is true in the groups of semantic loans with a label (S+L/ L+S) as well as graphic loan with a label $(\mathrm{G}+\mathrm{L} / \mathrm{L}+\mathrm{G})$. The latter type is still to be discussed below.

Loan blends $(\mathbf{S}+\mathbf{P} / \mathbf{P}+\mathbf{S})$. This is a category singled out in Haugen's classification but missing in Masini's. Loanwords in this group, as well as the phonetic-semantic loans (PS) belong to the overlapping part of the phonetic loan circle and the semantic one. Different from the phoneticsemantic loan which is a combination of phonetic and semantic loan simultaneously, a loan blend refers to the formation of loanwords which consist of a phonetic loan morpheme combined with a semantic loan morpheme whose sequence can though be permutated, e.g., 米老鼠 mílăoshǔ (Mickey Mouse) $(\mathrm{P}+\mathrm{S})$, 华尔街 huáérjiē (Wall Street) $(\mathrm{P}+\mathrm{S})$, 特洛伊木马 tèluòyīmùmă (Trojan horse) $(\mathrm{P}+\mathrm{S})$, 因特网 yīntèwăng Internet (lit., reason-special-net) $(\mathrm{P}+\mathrm{S})$ The sequence of the two elements can also be the opposite, i.e. a semantic loan morpheme is followed by a phonetic element, 作秀zuòxiù (make show) $(\mathrm{S}+\mathrm{P})$, 多媒体 (duōméitǐ) multimedia (lit., multi-intermediarybody) $(\mathrm{S}+\mathrm{P})$, 冰淇凌 bīngqílíng ice-cream (冰激凌bīngjīlíng), devoid of any meanings singly, $(\mathrm{S}+\mathrm{P})$, 毫巴 háobā millibar ( lit., 毫 háo milli, 巴 bā tail) $(\mathrm{S}+\mathrm{P})$.

Semantic loans. Implied by the semantic loan is a word or a phrase invented in Chinese on the basis of the morphological or syntactic structure of the foreign model. A semantic loan is different from a translation or a 'foreign concept word' in that the former bears morphological or syntactic similarity with the donor word. Hence 在线 zàixiàn (online, lit., on-line) is a semantic loan but 跑车 păochē (roadster, lit., running-vehicle) is not; 赛车 sàichē (racing car, lit., race-vehicle) is a semantic loan but跑车 (roadster, lit., running-vehicle) is not; 不明飞行物 bùmíngfēixíngwù (UFO) , unidentified flying object, lit., 不明 bùmíng unidentified, 飞行 fēixíng flying, 物 wù object) is a semantic loan but飞碟fēidié (UFO, lit., flying disc) is not. A semantic loan embraces three subgroups. One is the phonetic-semantic loan discussed above. The other two are calques (C) and semantic loans with a label $(\mathrm{S}+\mathrm{L} / \mathrm{L}+\mathrm{S})$.

However, many transliterations in Chinese have brought about obstacles for daily communication due to different versions of translation for one single word. Owing to this fact the various transliterations had to be unified and purified, or they had to be superseded by semantic loans. Semantic loans referred to as 意译词 yi-yi-ci (meaning-translation-word) in Mandarin, are words adopted by the recipient lexicon according to their meaning rather than pronunciation. In other words, semantic loans are expressions of the meaning of the loans by means of a phonetic and structural form of the recipient language. They can be divided into two subcategories according to the method of creating the Mandarin form. One is morpheme translation, by which the loan form derives from a morpheme-by-morpheme literal rendition of the source language form, e.g., Engl. download corresponds to Chin. 下载xia-za, lit. down load. This principle is even preserved during the adoption of structurally more sophisticated acronymic source language concepts, e.g., cf. Eng. Ebay and Chin. 电子湾 dian-zi-wan (electronics-bay). Also, respectively, Eng. FedEx corresponding to the Chin. 联邦快递 lian-bang-kuai-di (federal-express) and Eng. Microsoft entering the Chinese language as 微软 wei-ruan (small soft).

The other method is closer to a holistic translation, by which a loanword is reshaped in such a way that it captures the distinct features or functions of an alien object or concept, but with no morphemic correspondence between the borrowing and lending languages. For instance, the two exiting morphemes 电diàn (electric ) and 脑 năo (brain) may be joined to form a new word to denote the new referent 'computer'. This technique attempts to capture the most characteristic 
feature of the adopted concept. It would also be fitting and even quite common in the borrowing of trade marks, e.g., Eng. Sprite 'meaning wise' corresponds to 'snow-green jade', i.e, 雪碧 xue-bi and the brand name of shampoo Engl. Rejoice is adapted to 飘柔 piāoróu in Mandarin Chinese, which indicates the function of the hair-care product — to make the hair soft enough to float, cf. piāoróu 飘柔 (float-soft). A similar 'solution' is found in the adaptation of the brand name for a chewing gum Wrigley's which is rendered in Chinese as 绿箭lǜjiàn, lit. green-arrow (the latter two examples are given in Miao [16, p. 31].

Calques or loanshifts (C). A calque is a French word meaning "copy", also called by Heugen translation or loanshift [13, p. 211] terms. In linguistics, a calque or loan translation consists of the borrowing of a word or phrase from one language into another in the process of which individual words native to the borrowing language semantically matches the individual words in the source language, that is, each part of a loanword is literally translated from the donor word, e.g. 网络电 话 wăngluòdiànhuà netphone (lit., 网络 wăngluò net, 电话 diànhuà phone), 白领 báilǐng white collar (lit., 白领 báilǐng), 超人 chāorén superman (lit., 超 chāo super, 人 rén people), 键盘 jiànpán keyboard (lit., 键 jiàn key, 盘 pán plate), 泡沫经济 pàomòjīngjì bubble economy (lit. 泡沫 pàomò bubble, 经济 jīngjì economy).

Semantic loans with a label $(\mathbf{S}+\mathbf{L} / \mathbf{L}+\mathbf{S})$. As a typical Chinese way to adopt loanwords, a label indicating the category or field of the word and can be added to the phonetic loan morpheme (as seen above). It could be added to the semantic loan morpheme too. The label added to the semantic loan has similar functions as that added to the phonetic loan. Loanwords of this formation have been neglected in most of the researches on the classifications of loanwords because they occupy only a tiny percentage. They are exemplified by such cases as 鼠标 shǔbiāo mouse (lit., 鼠 mouse, 标 mark) (S+L) 鸡尾酒 jīwěijiǔ cocktail (lit., 鸡 jī cock, 尾 wěi tail, 酒 jiǔ alcohol) $(\mathrm{S}+\mathrm{L})$, 无线电 wúxiàndiàn wireless (lit., 无线 wúxiàn wireless, 电 diàn electronic) $(\mathrm{S}+\mathrm{L})$, 闪存 shăncún flash ( lit., shăn 闪 flash, cún 存 store) $(\mathrm{S}+\mathrm{L})$ and视窗 shì chuāngwindows (lit., 视 shì view, 窗 chuāng window) $(\mathrm{L}+\mathrm{S})$.

Graphic loans (G). The third approach to loanword adaptation in Mandarin is to borrow the written (or graphic) form of foreign words directly. Loans formed in this way are called graphic loans. Many researchers hold that such loanwords are borrowed from Japanese. Since the Japanese language was written in Chinese characters, Chinese speakers took the written form of the source terms directly and pronounced them in the Chinese way. For example, 'bungaku', or 文学, stands for literature.

Although Japan ceased to be the primary medium of Western knowledge for China after the 1940s, some words from Japanese continued to be borrowed in this way. Contemporary contacts between Mandarin and Japanese involve mainly economic activity, which leads to the importation of a large number of company names and brand names into Mandarin. For instance, Honda, an automobile brand, reads 本田 ben-tian, lit. root-field, and Toshiba, electronics brand, does 东芝 dong-zhi, lit. east-sesame. Also here belong the rare instances of graphitic translation: T-square' dīngzichī丁字尺, 'the Cross' shizìiià 十字架 and 'Z-shaped or 'zigzag' zhīzìxing之字 形 (examples adduced by Yip).

In addition to graphic loans from Japanese, a new type of graphic loans, namely words written in the Latin alphabet, have entered Mandarin since the late 1970s, spurred by increasing contact between Chinese and Western languages, especially English. The process of forming new words by combining only initial letter sequences of two or more words juxtaposed together is known as 'initialism' or 'acronym'. The former is generally verbalized letter by letter (e.g. CD 
and DV), while the latter is usually read or spoken as a single word (e.g. GMAT and TOFEL). Such words have been enormously on the increase in recent decades, especially in British and American journals, and Chinese has acquired its fair share of these abbreviations, which helps to save time and avoid awkward translations. For instance, ATM (Automated Teller Machine), BBS (bulletin board system); CD (Compact Disk), DIY (Do it yourself), IQ (intelligence quotient), MBA (Master of Business and Management), SIM (Subscriber Identification Module), WTO (World Trade Organization) get contextualized in the respective Chinese counterparts: e.g., WTO - 世 界贸易组织 [shijiemaoyizuzhi] CBD - 中央商务区 [zhongyangshangwuqu], GDP - 国内生产 总值 [guoneishengchanzongzhi], GDP - 国内生产总值 [guoneishengchanzongzhi], CEO - 执 行总裁 [zhixingzingcai].

A loanword will be borrowed in a form as close to the original as possible. Previous researches focused mainly on the two ways of being true to that original form; by copying the word's meaning (a calque/translation) and by copying the word's sound (a transliteration). Graphic loan, however, has not yet been recognized as an equally important way of borrowing.

According to Masini, graphic loans "are only possible if the languages share the same idiographic writing system and the relationship between the semantic and the graphic shape of the words is direct and not mediated by the phonemic shape" [14, p. 128].

The incidence of pure graphic loan, that is, a borrowed form alone without its sound or meaning is rare. In the novel “The story of Ah Q" (阿甘正传 āgānzhèngzhuàn), the famous Chinese writer Lu Xun (鲁迅 lǔxùn) used the capital letter Q to depict the figure of a head with a pigtail, a vivid portrait of a typical Chinese male before the May $4^{\text {th }}$ Movement in 1919. This might be the first letter used in Chinese. Though in the novel, Lu Xun introduced the pronunciation of Ah Q as 阿桂 āguì ((阿ā surname, 桂 guì laurel) people just pronounce the letter “Q” in English.

A comprehensive loan is a kind of direct and entire copy of the donor word, taking in all the three elements of sound, meaning and form simultaneously. It is also referred to as a direct borrowing or transference. The Chinese cognitive habit and traditional psychology used to reject this kind of borrowing. In modern times, however, this strategy has been gaining increasing popularity. A large number of letter words have penetrated into Chinese and got established so well that some of them become an indispensable element in Chinese, e.g., SOS, BBC, GRE, DIY, CT, VCD, E-mail.

Graphic-semantic loans (SG). In some cases, both the form and meaning of a word are borrowed. We call this graphic-semantic loan. Most of the words from Japanese are adopted in this way, e.g. cf. English science, conception, antipathy, object proposition, society, gas entryway with the Japanese counterparts (here given in their pronunciation) kagaku, gainer, hankan, taisho, meidai, shakaigasu that penetrated into Chinese, respectively, as 科学 kēxué, 概念 gàiniàn , 反感 făngăn 对象 duìxiàng 命题 mìngtí, 社会 shèhuì 瓦斯 wăsī, 手续 shǒuxù Masini’s graphic loans refer only to loanwords in this group [14]. He pays particular attention to the exchange between Chinese and Japanese and divides graphic loans from Japanese into two subtypes: original graphic loans and returned graphic loans. Original graphic loans are autochthonous Japanese words, e.g. 会 社 huìshè (company, lit., conference-agency) and 新闻 xīnwén (news, lit., new-hearing). Returned graphic loans once existed in earlier Chinese works but their meanings subsequently changed in Japanese, like 大学 dàxué (university, lit., big-study) and 天下 tiānxià (world, lit., sky-under).

Some graphic-semantic loans like signs and symbols can easily be taken for granted as native, thus escaping the researchers' attention. The Arabic numbers used all over the world are typical examples of this type. Most of the languages in the world adopt the 1-10 figures (the form) with 
the exact number they represent (adopting the meaning) but each language pronounces them differently (not adopting the sound).

Some of the English letters in Chinese are pronounced differently in some special contexts. For example, when playing cards, the card Jack is often called 尖jiān (lit., sharp) or 勾 gōu (lit., hook) and the card Queen is called 圈 quān (lit., circle) or 皮蛋pídàn (lit., egg). And letter X in windows XP is often called 叉 chā (lit., cross). The car plate beginning with 京 ( jīng ) J (京 jīng, which would be come across in Beijing, is always called 京勾 jīnggōu. Maybe 勾 gōu (lit., hook) is easier to pronounce and sounds louder than the English "J".

Graphic-phonetic loan. (PG) Sometimes the elements of a loanword copied are the form and the sound but not the meaning. For example, when Chinese borrows the English letters to depict the shape of something, we have V字领 zillnng (lit., 字 zì word, 领 lǐng collar), T型台xíngtái (lit. 型xíng type, 台 tái stage), U盘pán (lit., 盘pán disc), S钩 gōu (lit., 钩 gōu hook) and so on. The letters borrowed are pronounced in the English way. They are used in order to represent different shapes. Sometimes English letters are borrowed to represent the abbreviations of the Chinese phonetic alphabet, as in MM (美眉 měiméi, lit. beautiful eyebrow, referring to a beautiful girl on the net) and TMD (他妈的 tāmāde lit. his mother's, which stands for a common curse in Chinese).

Graphic loans with a categorizer. Similarly to phonetic loans with a label $(\mathrm{P}+\mathrm{L} / \mathrm{L}+\mathrm{P})$ and semantic loans with a label $(\mathrm{S}+\mathrm{L} / \mathrm{L}+\mathrm{S})$ a label showing up in pre- or postposition the category or field of the loanword can also be attached to the graphic loan morpheme, such as 量贩店 liàngfàndiàn (wholesale store) $(\mathrm{G}+\mathrm{L})$, 上班族 shàngbānzú working class (上班族shàngbānzú class/group) (L+G), PH值zhí (PH value 值zhí lit., figure/value) $(\mathrm{G}+\mathrm{L})$ and $\mathrm{PC}$ 机jī (personal computer, 机jī lit., machine) $(\mathrm{G}+\mathrm{L})$.

Calculus of types of loanwords. We can use the following table to summarize the above groups of loanwords according to the different level (Fregean vertices) elements they borrow from the donor words (table 1), which can also be overlapping in a single loanword (Fig. 1).

Table 1

Constituent level affiliation in the processes of English-Chinese borrowing

\begin{tabular}{|c|c|c|c|c|}
\hline Classification & type & ELEMENTS BORROWED & NOTATION & EXAMPLE \\
\hline 1 & 2 & 3 & 4 & 5 \\
\hline \multirow[t]{4}{*}{ Phonetic loan } & (1) & pure phonetic loan & $P$ & $\begin{array}{l}\text { 三明治 sānmíngzhì } \\
\text { sandwich }\end{array}$ \\
\hline & (2) & phonetic-semantic loan & PS & $\begin{array}{l}\text { 可口可乐 kěkǒukělè } \\
\text { Coca-cola }\end{array}$ \\
\hline & (3) & $\begin{array}{l}\text { hybrid or phonetic loan with } \\
\text { a label }\end{array}$ & $\mathrm{L}+\mathrm{P} / \mathrm{P}+\mathrm{L}$ & $\begin{array}{l}\text { Bar 酒吧jiǔbā ; } \\
\text { beer啤酒píjiǔ }\end{array}$ \\
\hline & (4) & loan blend & $\mathrm{P}+\mathrm{S} / \mathrm{S}+\mathrm{P}$ & $\begin{array}{l}\text { 作秀zuòxiù } \\
\text { make show, } \\
\text { 奶昔năixī milk shake }\end{array}$ \\
\hline \multirow[t]{2}{*}{ Semantic loan } & (5) & calque or loan shift & $\mathrm{S}$ & $\begin{array}{l}\text { 硅谷guīgǔ silicon } \\
\text { valley }\end{array}$ \\
\hline & (6) & semantic loan with a label & $\mathrm{S}+\mathrm{L} / \mathrm{L}+\mathrm{S}$ & $\begin{array}{l}\text { 鼠标shǔbiāo mouse , } \\
\text { 视窗shìchuāng } \\
\text { window }\end{array}$ \\
\hline
\end{tabular}




\begin{tabular}{|c|l|l|l|l|}
\hline \multicolumn{1}{|c|}{1} & \multicolumn{1}{|c|}{2} & \multicolumn{1}{|c|}{3} & \multicolumn{1}{c|}{ End Table 1 } \\
\hline \multirow{5}{*}{ Graphic loan } & (7) & comprehensive loan & PSG & WTO, VCD \\
\cline { 2 - 5 } & 8 & graphic-semantic loan & SG & $\begin{array}{l}\text { 料理 liàolǐ cooking } \\
\text { 人气rénqì popularity }\end{array}$ \\
\cline { 2 - 6 } & (9) & graphic-phonetic loan & PG & MM, RMB \\
\cline { 2 - 6 } & 10 & graphic loan with a label & G+L/ L+G & $\begin{array}{l}\text { 量贩店liàngfàndiàn } \\
\text { wholesale store, } \\
\text { SIM卡kă } \\
\text { SIM card }\end{array}$ \\
\hline
\end{tabular}

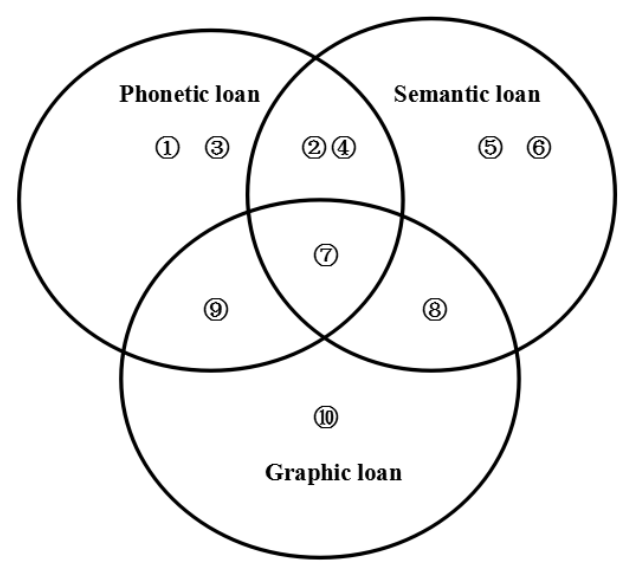

Figure 1. The overlaps of the Fregean triangle elements in a calculus of Anglicisms penetrating into the Chinese recipient lexicon

When there exist lexical gaps in the contacting languages new terms are needed to fill in the gaps and the easiest way of inventing such new terms is through lexical borrowing. Or sometimes English terms are preferred in order to establish a kind of identity (the basis for Englishization) to show power or solidarity. Loanwords are borrowed to fulfil either a referential function or an interpersonal function. They also have to go through the metalingual selection in order to establish themselves in the recipient language.

Since borrowing from English to Chinese is a process from a non-isolating language into an isolating language, and each morpheme in Chinese has both isolated phonological structure and isolated meaning, the mapping of a multi-syllabic non-isolating English word into Chinese must be a slow and conscious process.

Though there are instances that all three elements of a donor word, i.e. sound, meaning and form are borrowed, in most cases the strategy will favour one similarity over the other two. A foreign word will go through a series of selection processes before it is finally adopted.

In the phonetic privilege selection process, people first decide whether a foreign word (F) will be borrowed phonetically ( $+\mathrm{P}$ or $-\mathrm{P})$. The second step of choice is on whether to borrow semantically $(+\mathrm{S})$, which means that the Chinese characters still carry their original meaning, as 
in 可口可乐 kěkǒukělè instead of being used to represent the sound only (-S), such as is the case of 沙发 shāfā. The third step of selection is to decide whether to borrow graphically (+G or $-\mathrm{G})$. As a matter of fact, the second and third steps are interchangeable, so PSG is similar to PGS, and we can use the same example to indicate the selection process the other way around (cf. the respective notations on Fig. 2 and 3).

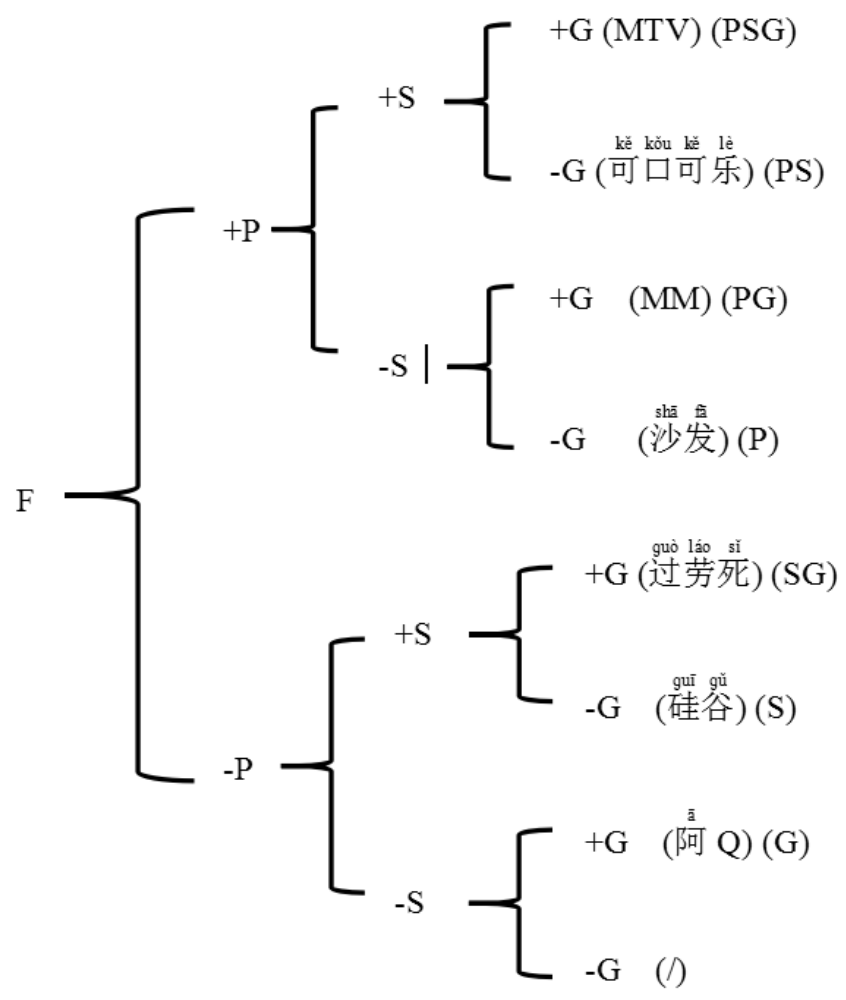

Figure 2. The functional selection of loanwords owing to a phonetic preference

More often though the semantic factor becomes the first element of functional selection, such as “new" in New Zealand being adopted semantically by 新 xīn (lit., new) (新西兰 xīnxīlán), which is in contrast with "new" in New York being accepted phonetically by 纽 niǔ (lit., pivot) ( 纽约 niǔyuē). Although Chinese has a special preference for semantic loans, there does not exist a rule to predict when to borrow semantically or phonetically. Explanations like the following are only partially true: 1 . A semantic loan is preferred when there is a corresponding equivalent of the referent in the borrowing language like the white house becoming 白宫 báigōng (lit., 白 bái white, 宫 gōng palace) ; 2. Semantic loan is preferred when the phonetic one turns into three or more Chinese characters, like "street” in Walt Street becoming 街 jiē, lit., street (华尔街 huá ěr jiē) rather than 斯翠特 sī cuì tè (lit., this-green-special) which is a pure phonetic transliteration.

By and large, the choice of a semantic loan versus a phonetic loan (Fig. 3) is to a very great extent arbitrary in the first place and conventional in the second. 


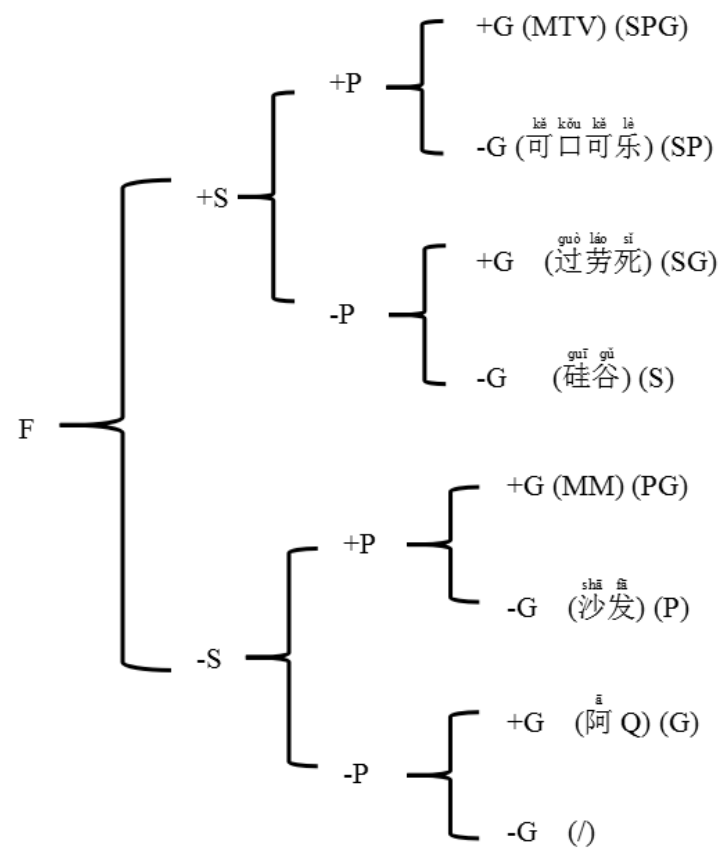

Figure 3. The functional selection of loanwords owing to a semantic preference

Graphic copying is not unique in Chinese. We can find a great many examples in English as well, such as the Roman numbers $I, I I, I I I, I V, V$ or some word spheres borrowed in the spelling of other languages, e.g. vis- $a$-vis. With the increasing of literacy and bilingualism in the population, as well as the popularity of computers and the network system in people's lives, graphic loans representing letter words become a new and powerful trend in loanwords in Chinese .

From the diagram we can see that a foreign word (F) can be borrowed either through the phonetic aspect $(\mathrm{P})$ or through the semantic aspect $(\mathrm{S})$ or through the graphic aspect $(\mathrm{G})$ only. A phonetically adopted loanword might go on facing the choice of whether to be adopted semantically or not and a third stage of choice, that is, whether to be accepted graphically, still exists. If a word is not adopted phonetically (-P), we can directly assume that it goes through the semantic selection and thus only two choices $(+\mathrm{G}$ or $-\mathrm{G})$ are left (Fig. 4). There is a rare case when a sign or symbol is borrowed only graphically, as the letter Q in 阿 ( $\bar{a})$ Q (the English IQ).

Though there are some reasons that account for the speakers' choices of the establishment of loanwords, the fundamental underlying principle might only be arbitrary. Therefore there does not exist a strong linear process of whether a loanword should be adopted phonetically first or semantically or graphically. Besides, it is not necessary to present the empty stage of "-P-S-G" since no such circumstance exists. To avoid the large overlapping part in the above three diagrams, we can combine them into one as follows (Fig. 5).

The suggested formalized model of the loans calculus reflects the interplay of the Fregean vertexes in the onomasiology of the links of the lexical contacts between English and Chinese, although it overlooks the element of domestication on the part of the categorizer feature in the 


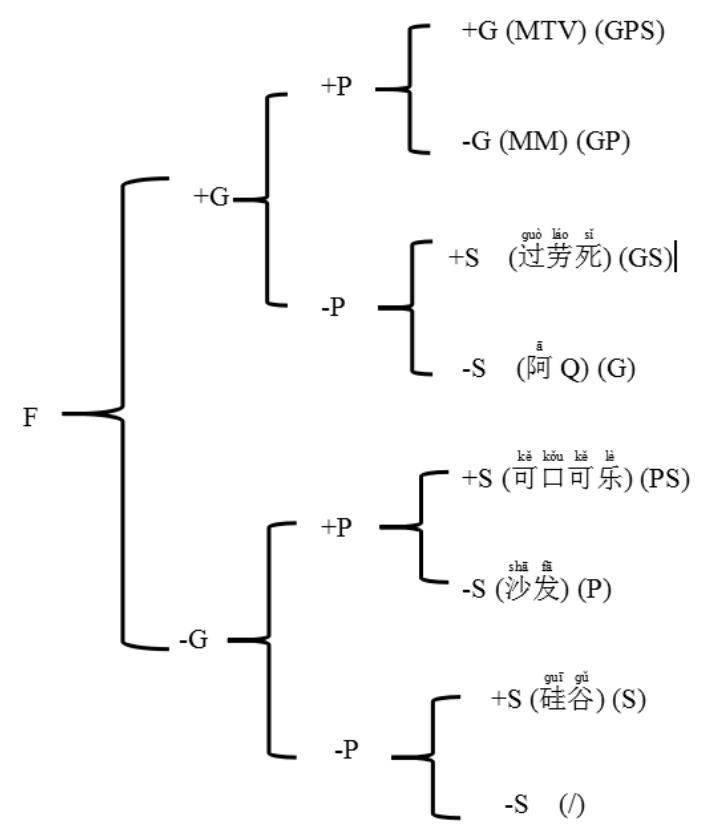

Figure 4. The functional selection of loanwords owing to a graphic preference

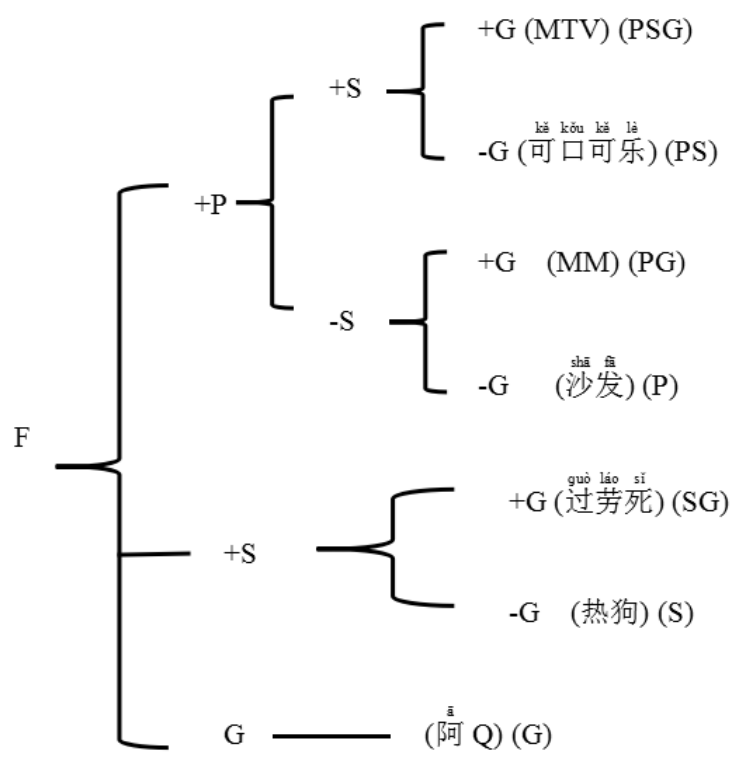

Figure 5. The functional selection of Anglicisms in Chinese owing to modus-relevant preferences 
lexified counterpart of this situation. The diagram excludes loanwords with a sense lable attachment (No.3 (P+L), No.6 (S+L) and No. $10(\mathrm{G}+\mathrm{L})$ in table 1$)$.

The analysis of Chinese Anglicisms along the line of modus-sensitive and adoption-induced features is deemed to be conducive to an adequate assessment of the versatility of contact scenarios between the typologically distant languages.

\section{Список використаної літератури}

1. Архипенко К. Принципи словоскладання англомовних лексичних запозичень в сучасній китайській мові / К. Архипенко // Мовні і концептуальні картини світу. - зб. наук. пр. - Вип. 36. 2011. - C. 5-62.

2. Борисова О. С. Пути и источники заимствования в китайском языке / О. С. Борисова // Альманах современной науки и образования. - No 8 (15): в 2-х ч. - Тамбов : Грамота, 2008. C. $21-25$.

3. Гончаренко О.М.Іншомовні запозичення у сучасній китайській мові в контексті глобалізації / О. М. Гончаренко // Мовні і концептуальні картини світу. - зб. наук. пр. - Вип. 1. - 2015. C. $160-168$.

4. Котельникова Н. Англоязычные заимствования как элемент лингвистической глобализации современного китайского языка / Н. Котельникова // Китайська цивілізація: традиції та сучасність: [зб. науч. ст.] - К., 2005. - С. 34-37.

5. Семенас А. Л. Особенности лексических заимствований в китайском языке / А. Л. Семенас // Вопросы языкознания. - № 1. - 1997. - С. 48-57.

6. Сяобай Л. Англицизмы и китаефикация: заимствования из английского языка и процессы их освоения в китайском языке / Л. Сяобай, Е. В. Полищук // Вестник ТвГУ. Серия “Филология”. - № 4. - 2016. - С. 130-135.

7. Торчакова Н. В. Проблемы адаптации фонетических и семантических заимствований в китайском языке : диахронический аспект / Н. В. Торчакова, А. Г. Фомин // Вестник КемГУ. Филология. - № 4 (52). - 2012. - С. 178-182.

8. Bauer R. S. The stratification of English loanwords in Cantonese / R. S. Bauer // Journal of Chinese Linguistics. - Vol. 34. - No. 2. - 2006. - P. 172-191.

9. Bulfoni C. Lexical Borrowing from English in the Internet Era: How to Preserve Chinese Identity? / C. Bulfoni // Identities across Media and Modes: Discursive Perspectives Series: Linguistic Insights [Giuliana Elena Garzone and Paola Catenaccio eds.]. - Frankfurt : Peter Lang AG, 2011. P. 215-234.

10. Fang Q. Translingual creativities: a sociolinguistic case study of English lexical borrowings in Mandarin from perspectives of language contact. / Qi Fang, Mo Shaobin // Asian Englishes. 18: 1. - 2016. - P. 19-35.

11. Feng Zh. The Semantic Loanwords and Phonemic Loanwords in Chinese Language / Zh. Feng // 《Aspects of Foreign Words/Loanwords in the Word's language》(The Multi-Faceted Nature of Language Policies that Aim to Standardize and Revive Language), Proceedings for 11th International Symposium. The National Institute for Japanese Language. - Tokyo, 2004. - P. 200-229.

12. Gao L. W. The lexical acculturation of English in the Chinese context / L. W. Gao // Studies in the Linguistics Sciences. - No. 31. - 2001. - P. 73-78.

13. Haugen E. The analysis of linguistic borrowing / E. Haugen // Language. -26(2) - 1950. -210-231.

14. Masini F. The formation of Modern Chinese lexicon and its evolution toward a national language: The period from 1840 to 1898 / F. Masini // Journal of Chinese Linguistics. - No 6. - 1993. - 295 p.

15. Miao R. Loanwords / R. Miao // Routledge Encyclopedia of the Chinese Language / S.-W. Chan, ed. - London and New York : Routledge, 2016. - P. 563-578. 
16. Miao R. Loanword adaptation in Mandarin Chinese: Perceptual, phonological and sociolinguistic factors / R. Miao [Doctoral dissertation]. - Stony Brook : State University of New York, 2005. Retrieved from https://linguistics.stonybrook.edu/sites/default/files/uploads/Miao_2005.pdf

17. Novotna Z. Contributions to the study of loan-words and hybrid words in Modern Chinese / Z. Novotna // Archiv orientalni. - Vol. 35. - No 4. - Praha, 1967. - P. 613-648.

18. Sun H. A study of recent borrowings in Mandarin / H. Sun, K. Jiang // American Speech. - 75(1). $-2000 .-$ p. $98-106$.

19. T'sou B. K. Language contact and lexical innovation / B. K. T'sou // New Terms for New Ideas. Western Knowledge and Lexical Change in Late Imperial China [M. Lackner, I. Amelung and J. Kurtz (eds.)]. - Leiden et al : 2001. - P. 35-56.

20. Tian A. Transliteration or Loan Translation: Constraints on English Loanwords' Integration into Mandarin Chinese Tilburg Papers in Culture Studies / A. Tian, A. Backus. - Paper 44. - 2013. - 16 p.

21. Tian F. Orthographic Constraints on the Integration of English Loanwords in Mandarin Chinese / F. Tian // Theory and Practice in Language Studies. - 2(5). - 2012. - P. 965-971.

22. Zheng M. English loanwords in Mandarin Chinese: a perception experiment approach / M. Zheng, K. Durvasula // Proceedings of the 27th North American Conference on Chinese Linguistics (NACCL-27). - Vol. 2. - Los Angeles : UCLA, 2015. - P. 462-480.

23. Zhu K. On Chinese-English language contact through loanwords / K. Zhu // English Language and Literature Studies. - Vol. 1. - No. 2 (December). - 2011. - P. 100-105.

24. Zuckermann G. Language contact and globalisation: the camouflaged influence of English on the world's languages - with special attention to Israeli (sic) and Mandarin / G. Zuckermann // Cambridge Review of International Affairs. - 16/2. - 2003. - P. 287-307.

\section{References}

1. Arkhypenko K. Pryntsypy slovoskladannia anhlomovnykh leksychnykh zapozychen v suchasniy kytaiskiy movi / K. Arkhypenko // Movni i kontseptualni kartyny svitu. - zb. nauk. pr. - Vyp. 36. $-2011 .-$ S. $5-62$.

2. Borisova O. S. Puti i istochniki zaimstvovaniia v kitaiskom yazyke / O. S. Borisova // Almanakh sovremennoy nauki i obrazovaniya. - No 8 (15): v 2-h ch. - Tambov : Gramota, 2008. - S. 21-25.

3. Honcharenko O. M. Inshomovni zapozychennia u suchasniy kytaiskiy movi v konteksti globalizatsii / O. M. Honcharenko // Movni i kontseptualni kartyny svitu. - zb. nauk. pr. - Vyp. 1. - 2015. S. 160-168.

4. Kotelnikova N. Angloyazychnye zaimstvovaniya kak element lingvisticheskoi globalizatsii sovremennogo kitaiskogo yazyka / N. Kotelnikova // Kytaiska tsyvilizatsiya: tradytsii ta suchasnist : [zb. nauch. st.] - K., 2005. - S. 34-37.

5. Semenas A. L. Osobennosti leksicheskikh zaimstvovaniy v kitaiskom yazyke / A. L. Semenas // Voprosy yazykoznaniya. - № 1. - 1997. - S. 48-57.

6. Siaobai L. Anglitsyzmy i kitaefikatsiya: zaimstvovaniya iz angliiskogo yazyka i protsessy ikh osvoeniya v kitaiskom yazyke / L. Siaobai, Ye. V. Polishchuk // Vestnik TvGU. Seriya "Filologiya". № 4. - 2016. - S. 130-135.

7. Torchakova N. V. Problemy adaptatsyi foneticheskikh i semanticheskikh zaimstvovaniy v kitaiskom yazyke : diakhronicheskiy aspekt / N. V. Torchakova, A. G. Fomin // Vestnik KemGU. Filologiya. № 4 (52). - 2012. - S. 178-182.

8. Bauer R. S. The stratification of English loanwords in Cantonese / R. S. Bauer// Journal of Chinese Linguistics. - Vol. 34. - No. 2. - 2006. - P. 172-191.

9. Bulfoni C. Lexical Borrowing from English in the Internet Era: How to Preserve Chinese Identity? / C. Bulfoni // Identities across Media and Modes: Discursive Perspectives Series: Linguistic 
Insights [Giuliana Elena Garzone and Paola Catenaccio eds.]. - Frankfurt : Peter Lang AG, 2011. P. 215-234.

10. Fang Q. Translingual creativities: a sociolinguistic case study of English lexical borrowings in Mandarin from perspectives of language contact. / Qi Fang, Mo Shaobin // Asian Englishes. - 18: 1. 2016. - P. 19-35.

11. Feng Zh. The Semantic Loanwords and Phonemic Loanwords in Chinese Language / Zh. Feng // 《Aspects of Foreign Words/Loanwords in the Word's language》(The Multi-Faceted Nature of Language Policies that Aim to Standardize and Revive Language), Proceedings for 11th International Symposium. The National Institute for Japanese Language. - Tokyo, 2004. P. 200-229.

12. Gao L. W. The lexical acculturation of English in the Chinese context / L. W. Gao // Studies in the Linguistics Sciences. - No. 31. - 2001. - P. 73-78.

13. Haugen E. The analysis of linguistic borrowing / E. Haugen // Language. -26(2). - 1950 - 210-231.

14. Masini F. The formation of Modern Chinese lexicon and its evolution toward a national language: The period from 1840 to 1898 / F. Masini // Journal of Chinese Linguistics. - No 6. - 1993. - 295 p.

15. Miao R. Loanwords / R. Miao // Routledge Encyclopedia of the Chinese Language / S.-W. Chan, ed. - London and New York : Routledge, 2016. - P. 563-578.

16. Miao R. Loanword adaptation in Mandarin Chinese: Perceptual, phonological and sociolinguistic factors / R. Miao [Doctoral dissertation]. - Stony Brook : State University of New York, 2005. Retrieved from https://linguistics.stonybrook.edu/sites/default/files/uploads/Miao_2005.pdf

17. Novotna Z. Contributions to the study of loan-words and hybrid words in Modern Chinese / Z. Novotna // Archiv orientalni. - Vol. 35. - No 4. - Praha, 1967. - P. 613-648.

18. Sun H. A study of recent borrowings in Mandarin / H. Sun, K. Jiang // American Speech. - 75(1). 2000. - p. 98-106.

19. T'sou B. K. Language contact and lexical innovation / B. K. T'sou // New Terms for New Ideas. Western Knowledge and Lexical Change in Late Imperial China [M. Lackner, I. Amelung and J. Kurtz (eds.)]. - Leiden et al : 2001. - P. 35-56.

20. Tian A. Transliteration or Loan Translation: Constraints on English Loanwords' Integration into Mandarin Chinese Tilburg Papers in Culture Studies / A. Tian, A. Backus. - Paper 44. - 2013. - 16 p.

21. Tian F. Orthographic Constraints on the Integration of English Loanwords in Mandarin Chinese / F. Tian // Theory and Practice in Language Studies. - 2(5). - 2012. - P. 965-971.

22. Zheng M. English loanwords in Mandarin Chinese: a perception experiment approach / M. Zheng, K. Durvasula // Proceedings of the 27th North American Conference on Chinese Linguistics (NACCL-27). - Vol. 2. - Los Angeles : UCLA, 2015. - P. 462-480.

23. Zhu K. On Chinese-English language contact through loanwords / K. Zhu // English Language and Literature Studies. - Vol. 1. - No. 2 (December). - 2011. - P. 100-105.

24. Zuckermann G. Language contact and globalisation: the camouflaged influence of English on the world's languages - with special attention to Israeli (sic) and Mandarin / G. Zuckermann // Cambridge Review of International Affairs. - 16/2. - 2003. - P. 287-307. 


\title{
АНГЛІЙСЬКІ ЗАПОЗИЧЕННЯ У КИТАЙСЬКІЙ МОВІ: ФРЕГЕАНСЬКА ТИПОЛОГІЯ ТА ЧИННИКИ ПРАГМАТИЧНОЇ ПРЕФЕРЕНЦІЇ
}

\author{
Юнгмінг Ванг \\ Львівський національний університет імені Івана Франка \\ вул. Університетська, 1, Львів, Украӥна, 79000 \\ lvcc66501@163.com
}

У статті подано огляд англійських запозичень у словниковому складі китайської мови 3 особливою увагою на копіюванні та адаптуванні фонетичних, значеннєвих, референційних та графічних властивостей у процесах засвоєння англіцизмів китайським лексичним середовищем. На підставі взаємодії цих чинників виділено та проілюстровано десять класів англійських запозичень у китайській мові. Запропоновано моделі прагмакогнітивної преферентності, яку надають мовці модусним (за ієрархією рівнів) властивостям елементів мови-джерела у їхньому перевтіленні та засвоєнні під час сценаріїв міжкультурної взаємодії.

Ключові слова: запозичення, засвоєння, лексикон китайської мови, англіцизми, міжкультурна взаємодія 